\title{
Ocena skutków regulacji zawartych w komisyjnym projekcie ustawy o zapewnieniu godnej pamięci i należytej ochrony miejscom spoczynku Bohaterów Powstania Warszawskiego oraz innych osób zasłużonych w walkach o niepodległość i suwerenność Państwa Polskiego (druk sejmowy nr 2920) ${ }^{1}$
}

\begin{abstract}
Impact assessment of rules of the committee Bill on Ensuring Decent Remembrance and Proper Protection of Burial Places of Heroes of the Warsaw Uprising and Other Persons of Merit Participating in Struggles for the Independence and Sovereignty of the Polish State (Sejm's paper no. 2920): The bill regulates matters related to the protection of historical memory about persons of mertit participating in struggles for the independence and sovereignty of Poland, in particular in the Warsaw Uprising. Entry into force of the proposed act will cause financial effects for the state budget in the form of increased spending. The explanatory statement to the bill not include any information about the costs, even estimated ones, of maintaining and renovating burial places covered by the prohibition on reburial, as well as about the criteria for distribution of funds intended for financing the purposes determined in the Act. Moreover sources of funds of the state budget from which the undertakings provided in bill would be financed have not been specifies. The author also expresses doubts about the compatibility of the procedure for issuing the decision on the prohibition of using the grave for reburial with Article 2 of the Constitution of the Republic of Poland, due to its rudimentary character, which results in the lack of legal certainty.
\end{abstract}

Keywords: state budget, cemetery, grants, Institute of National Remembrance, impact assessment, bill

Słowa kluczowe: budżet państwa, cmentarz, dotacje, Instytut Pamięci Narodowej, ocena skutków regulacji, projekt ustawy

Doktor hab. nauk prawnych, profesor UŁ, Wydział Prawa i Administracji

Uniwersytetu Łódzkiego, ekspert ds. legislacji BAS - hdzwonkowski@poltax.pl • https://orcid.org/0000-0002-7110-3029

1 Ocena skutków regulacji zawartych $w$ Komisyjnym projekcie ustawy o zapewnieniu godnej pamięci i należytej ochrony miejscom spoczynku Bohaterów Powstania Warszawskiego oraz innych osób zasłużonych $w$ walkach o niepodległość i suwerenność Państwa Polskiego (druk 2920) sporządzona 16 listopada 2018 r. na zlecenie zastępcy Szefa Kancelarii Sejmu; BAS-WASiE 2429/18. 


\section{Zakres przedmiotowy projektu ustawy}

Zakresem przedmiotowym projektu objęte są kwestie związane z ochroną pamięci historycznej o osobach zasłużonych w walkach o niepodległość i suwerenność Polski, w tym w szczególności w powstaniu warszawskim. Projekt wpływa na sektor finansów publicznych, gdyż przewiduje finansowanie zmian $\mathrm{z}$ budżetu państwa.

\section{Podmioty, na które oddziałuje akt}

Oddziaływaniem projektu objęte są: Instytut Pamięci Narodowej - Komisji Ścigania Zbrodni Przeciwko Narodowi Polskiemu (IPN) i jego pracownicy, organy władzy publicznej - zarówno organy administracji rządowej i samorządu terytorialnego i ich pracownicy, jak i organizacje społeczne zajmujące się upamiętnianiem i otaczaniem opieką miejsc pamięci narodowej, członkowie rodzin osób zmarłych, o których mowa w art. 10 ust. 1 ustawy z 31 stycznia 1959 r. o cmentarzach i chowaniu zmarłych (t.j. Dz.U. 2017, poz. 912, ze zm.; dalej: ustawa o cmentarzach). Projekt może pośrednio wywołać skutki także dla członków rodzin osób pochowanych w mogiłach objętych decyzjami o zakazie ponownego wykorzystania miejsca pochówku².

\section{Celowość wprowadzenia aktu}

Celem wprowadzenia aktu jest zapewnienie godnej pamięci i należytej ochrony miejscom pochówku osób walczących w powstaniu warszawskim oraz innych osób zasłużonych w walkach o niepodległość Polski poprzez wyłączenie niektórych miejsc pochówku od możliwości ponownego użycia grobu oraz przeznaczanie środków publicznych na ich utrzymanie i remonty. Konieczność wprowadzenia regulacji nie wynika z prawa Unii Europejskiej ani norm prawa międzynarodowego. Osiągnięcie celu nie jest ściśle określone w czasie. Działania przewidziane $\mathrm{w}$ projekcie mają mieć co do zasady charakter ciągły, nakierowany na ochronę miejsc spoczynku w długim horyzoncie czasowym. W ustawie wyznacza się dwa terminy - termin sześciu miesięcy na utworzenie Bazy Miejsc Spoczynku - liczony od dnia wejścia w życie ustawy oraz termin dwuletni na przedstawienie przez Prezesa IPN Sejmowi RP informacji dotyczącej działań zmierzających do osiągnięcia założonego $\mathrm{w}$ ustawie celu. Biorąc pod uwage 14-dniowy termin vacatio legis przewidziany w ustawie, można przypuszczać, że

2 Projekt może pośrednio oddziaływać także na przedsiębiorców zajmujących się m.in. zabiegami konserwatorskimi czy remontowo-kamieniarskimi. 
w okresie po wejściu w życie przepisów, a przed utworzeniem Bazy Miejsc Spoczynku nie będzie technicznej możliwości dokonania wpisu do tej bazy, mimo wydania decyzji administracyjnej w tej sprawie. Jako miernik efektów wprowadzenia nowej ustawy można wskazać liczbę miejsc pochówku zarejestrowanych w Bazie Miejsc Spoczynku administrowanej przez Prezesa Instytutu Pamięci Narodowej i objętych ochroną.

\section{Planowane środki (narzędzia i działania) realizacji celów}

Cele wskazane w projekcie mają zostać osiągnięte przez wyposażenie Prezesa IPN w nowe kompetencje. W szczególności dotyczą one możliwości wydania decyzji o zakazie użycia grobu do ponownego pochowania oraz prowadzenia Bazy Miejsc Spoczynku. W projekcie przewiduje się również, że koszty utrzymania oraz remontów grobów, wobec których wydano decyzję o zakazie ich użycia do ponownego pochówku, będą ponoszone ze środków budżetu państwa. Nie ma możliwości oceny, czy środki finansowe byłyby wystarczające do osiągnięcia założonych celów, gdyż w projekcie nie wskazano, jakie nakłady finansowe zostaną przeznaczone na przeprowadzenie założonych działań. O ile instytucja zakazu wykorzystania grobu do ponownego pochówku może zostać uznana za właściwy środek do osiągnięcia założonego celu, czyli ochrony pamięci osób zasłużonych w walkach o niepodległość, o tyle automatyczne objęcie utrzymania i remontu miejsc pochówku finansowaniem z budżetu państwa może budzić wątpliwości. Warte rozważenia jest, czy finansowanie z budżetu państwa nie powinno następować na wniosek członka rodziny, który nie jest w stanie takich kosztów ponieść (chyba że nie istnieją żyjący członkowie rodziny osoby zmarłej), bądź organizacji społecznej zajmującej się upamiętnianiem i otaczaniem opieką miejsc pamięci narodowej.

W przewidzianej nowelizacji ustawy z 6 czerwca 1997 r. - Kodeks karny (t.j. Dz.U. 2018, poz. 1600, ze zm.) przewiduje się również stworzenie typu kwalifikowanego przestępstwa znieważenia miejsca pochówku ze zwiększoną granicą ustawowego zagrożenia karą pozbawienia wolności (do 3 lat). W odniesieniu do tego typu przestępstwa będzie możliwe orzeczenie nawiązki na wskazany cel społeczny związany z ochroną miejsc spoczynku, wobec których Prezes IPN wydał decyzję o zakazie ponownego pochówku.

\section{Ocena kosztów i korzyści}

\section{Skutki finansowe}

W uzasadnieniu projektu ustawy wskazano, że projekt wywoła skutek w postaci obciążenia budżetu państwa, jednak nie oszacowano chociażby przybliżonej wielkości wydatków związanych z wdrożeniem propozycji przewidzianych 
w ustawie. Odnosząc się do treści projektu, należy mieć na względzie, że wprowadzenie planowanych rozwiązań wygeneruje koszty w kilku obszarach.

- Koszt utworzenia Bazy Miejsc Spoczynku. W projekcie nie wskazano, czy ma to być baza elektroniczna, jednak można przyjąć, że w związku z dążeniem do cyfryzacji administracji państwowej większą funkcjonalność gwarantowałaby właśnie baza elektroniczna. W związku z tym zachodziłaby zatem konieczność utworzenia elektronicznej struktury danych.

- Koszt obsługi Bazy Miejsc Spoczynku, zapewnienia IPN kadr do wydawania decyzji o zakazie ponownego pochówku czy prowadzenia badań dotyczących istnienia w kraju i za granicą miejsc spoczynku osób, o których mowa w art. 2 ust. 1 projektu. Koszty te obejmują utworzenie nowych miejsc pracy, w tym wyposażenia ich w niezbędny sprzęt, jak również koszty ewentualnego najmu powierzchni, jeśli IPN nie dysponuje wolnymi przestrzeniami do ulokowania nowych pracowników. Dodatkowe koszty mogą też wiązać się z nową kompetencją w zakresie oceniania stanu opieki nad grobami osób, o których mowa w art. 2 ust. 1 projektu, z uwagi na konieczność dokonywania czynności na terenie całego kraju, należy rozważać ewentualne koszty delegacji pracowników IPN, w sytuacji gdyby zachodziła konieczność np. dokonania oględzin miejsca pochówku.

- Koszty utrzymania i remontu nagrobków. Koszty utrzymania nagrobków, poza bieżącymi pracami porządkowymi, mogą obejmować także koszty opłat cmentarnych związanych z utrzymywaniem grobów przez okres dłuższy niż 20 lat. Koszty remontu nagrobków będą zależne od stanu miejsca pochówku oraz tego czy i jaki znajduje się na nim nagrobek. Mogą obejmować koszty prac konserwacyjnych. W odniesieniu do nagrobków będących pod nadzorem konserwatora zabytków mogą wystąpić znaczne koszty ewentualnej rekonstrukcji.

Należy mieć na względzie, że precyzyjne wskazanie kwoty wydatków, jakie wygeneruje projekt, jest utrudnione, jednak biorąc pod uwagę doświadczenie życiowe i realia obrotu gospodarczego, można założyć, że koszt wykonania Bazy może wynieść kilkadziesiąt tysięcy złotych, roczne koszty ewentualnego zatrudnienia nowych pracowników przez IPN i wyposażenia ich stanowisk pracy (w zależności od liczby zatrudnionych osób) wyniosą nie mniej niż kilkadziesiąt tysięcy złotych w skali roku na jednego pracownika. Koszt ewentualnej pojedynczej opłaty cmentarnej może zaś wynieść nawet kilka tysięcy złotych i jest uzależniony od miejsca położenia grobu. Koszty remontów i konserwacji mogą oscylować od kilkuset do nawet kilkudziesięciu tysięcy złotych (nagrobki zabytkowe). Na marginesie należy wspomnieć, że próbę oszacowania kosztów analogicznych działań jak opisane w projekcie podjęto w uzasadnieniu rządowego projektu ustawy o grobach weteranów walk o wolność i niepodległość Polski (druk nr 2902), również zawierającym propozycje ochrony miejsc spoczynku 
weteranów. Koszty utworzenia bazy szacuje się w tym akcie na około 40 tys. zł, a roczny koszt zatrudnienia 25 pracowników IPN, wraz z wyposażeniem stanowisk pracy na ponad 1,5 mln zł. W świetle powyższych konstatacji zasadne jest twierdzenie, że potrzeby finansowe związane z projektem mogą być znaczne. W uzasadnieniu ustawy nie wskazano jednak (poza ogólnym zastrzeżeniem, że pochodzą one z budżetu państwa) źródeł pozyskania środków na finansowanie zadań opisanych w projekcie, co wymaga uzupełnienia.

\section{Skutki społeczne}

Objęcie ochroną grobów osób walczących o niepodległość kraju przez wyłączenie możliwości likwidacji grobów osób zasłużonych w walce o niepodległość kraju może wywołać pozytywne skutki społeczne w postaci zwiększenia świadomości historycznej społeczeństwa, w tym członków społeczności lokalnych. Jednak należy mieć na względzie, że projektowana regulacja może budzić również kontrowersje i niepokoje społeczne, chociażby w zakresie, w jakim przewiduje uznaniowość decyzji Prezesa IPN o zakazie ponownego wykorzystania grobu do pochówku. W nowo projektowanym art. 7a ustawy o cmentarzach nie wymienia się kryteriów branych pod uwagę przy wydawaniu wskazanej wyżej decyzji. W ust. 8 powołanego przepisu przewiduje się również, że decyzja taka może zostać następczo uchylona $z$ urzędu lub na wniosek uprawnionego podmiotu, przy czym w treści przepisu także nie precyzuje się katalogu przesłanek warunkujących jej uchylenie.

Wątpliwości może budzić też ogólnikowość postanowień art. 7b ustawy o cmentarzach. O ile zamysł ochrony i podjęcia działań mających na celu utrzymanie w godnym stanie miejsc spoczynku osób walczących o niepodległość Polski należy oceniać pozytywnie, o tyle trzeba rozważyć, czy automatyczne finansowanie utrzymania i remontów wszystkich miejsc pochówku, wobec których wydano decyzję o zakazie ponownego wykorzystania grobu, ze środków budżetu państwa jest zasadne. W sytuacji bowiem, gdy miejsce spoczynku wskazanej osoby nie jest objęte opieką rodziny bądź rodzina znajduje się w trudnej sytuacji materialnej i nie jest w stanie wyasygnować środków na zachowanie miejsca pochówku w godnym stanie, przeznaczenie określonych środków publicznych na zabezpieczenie miejsca pochówku może się okazać słuszne. W odniesieniu do grobów znajdujących się pod opieką rodziny bądź innych osób, które są w stanie zapewnić im utrzymanie i remonty, przeznaczanie dodatkowych środków finansowych z budżetu państwa na ten cel może budzić kontrowersje, zwłaszcza jeśli rodzina nie występuje z wnioskiem o przyznanie pomocy finansowej na ten cel.

W projekcie nie została również opisana procedura rozdysponowywania środków przeznaczonych na utrzymanie i remonty miejsc pochówku, w szczególności nie wskazano, w jaki sposób i jak często będzie dokonywana ocena stanu miejsca pochówku, czy na każde miejsce spoczynku będą przeznaczane środki na utrzymanie co roku, czy istnieje jakiś limit wydatków, które mogą być poczynione w danym roku na realizację ustawowego celu. 


\section{Skutki administracyjno-organizacyjne}

Wejście w życie projektu spowoduje wyposażenie Prezesa IPN oraz pracowników IPN w dodatkowe kompetencje, w tym w zakresie wydawania decyzji o zakazie wykorzystania grobu do ponownego pochówku, uchylania tych decyzji, prowadzenia Bazy Miejsc Spoczynku i dokonywania w niej wpisów, jak również prowadzenia badań dotyczących istnienia w kraju i za granicą miejsc spoczynku osób, o których mowa w art. 2 ust. 1 projektu. Powyższe spowoduje konieczność zatrudnienia nowych pracowników w Instytucie Pamięci Narodowej bądź reorganizację pracy osób dotychczas zatrudnionych, przez przekazanie im dodatkowych obowiązków i przesunięcie do wykonywania dodatkowych zadań. W uzasadnieniu projektu nie wskazuje się jednak, czy IPN takimi zasobami pracowników dysponuje. Ewentualne zatrudnienie nowych pracowników będzie się wiązało z koniecznością zagwarantowania im zaplecza lokalowego oraz wyposażenia stanowisk pracy. Wprowadzenie zmian przewidzianych $\mathrm{w}$ projekcie spowoduje także konieczność utworzenia nowej struktury danych, jaką jest Baza Miejsc Spoczynku i zapewnienia jej stałego funkcjonowania.

\section{Skutki prawne}

Poddając ocenie treść projektu w kontekście jej zgodności z art. 5 Konstytucji RP, można przyjąć, że w tym zakresie niezgodność z Konstytucją nie zachodzi. Strzeżenie dziedzictwa narodowego to: wymóg ochrony wszystkich czynników natury materialnej i duchowej zaistniałych $w$ historii państwa i społeczeństwa polskiego, świadczących o jego tożsamości, równej pozycji wśród innych narodów, a także stanowiacych zaczyn dalszego rozwoju ${ }^{3}$. Jednym ze sposobów ochrony wymienionych czynników materialnych może być objęcie szczególną opieką miejsc pochówku osób zasłużonych w walkach o niepodległość Polski.

Wątpliwości co do zgodności z art. 2 Konstytucji RP, gwarantującego pewność prawa i ochronę zaufania obywateli do państwa i tworzonego przez nie prawa, może jednak budzić wyłączenie stosowania w odniesieniu do decyzji o zakazie ponownego wykorzystania miejsca spoczynku na pochówek przepisów ustawy - Kodeks postępowania administracyjnego (art. 7a ust. 3 ustawy o cmentarzach). Zdaniem autorów projektu wyrażonym w uzasadnieniu projektu nie ma potrzeby, by decyzja była wydawana w klasycznym postępowaniu administracyjnym, gdyż: [...] nie wpływa bezpośrednio na status prawny jednostek, lecz ma głównie charakter ustrojowy i symboliczny, służy bowiem realizacji zadań państwa zwiazanych z obowiązkiem stania na straży dziedzictwa narodowego. Z tego względu proponuje się, aby rozstrzygnięcie było wydawane zgodnie z trybem wskazanym w art. 7a ust. 4 i 5 ustawy o cmentarzach - art. 4 projektu.

3 Konstytucja Rzeczypospolitej Polskiej. Komentarz, t. I, red. L. Garlicki, M. Zubik, Warszawa 2016. 
Odnosząc się do powyższego, należy mieć na względzie, że samo uregulowanie trybu wydawania decyzji, o którym mowa w art. 7a ust. 4 i 5 ustawy o cmentarzach, ma charakter szczątkowy i nie zawiera istotnych elementów umożliwiających zgodne $\mathrm{z}$ art. 2 Konstytucji RP funkcjonowanie procedury wydawania decyzji. Wskazane przepisy nie regulują m.in. terminu załatwienia sprawy, zwłaszcza w sytuacji gdy wydanie decyzji ma nastąpić na wniosek. Przepisy nie normują także zakresu uprawnień wnioskodawcy, w szczególności nie gwarantują mu czynnego udziału w postępowaniu, w tym możliwości zapoznania się z materiałami zgromadzonymi w sprawie. Nie uregulowano także kwestii doręczeń. W odniesieniu do możliwych rozstrzygnięć sprawy dotyczącej objęcia miejsca spoczynku zakazem wykorzystania do ponownego pochówku, wart. 7a ust. 1 ustawy o cmentarzach wskazano jedynie, że Prezes IPN może wydać decyzję o zakazie użycia grobu do ponownego pochowania. Nie wskazuje się zatem, czy poza wydaniem takiej decyzji Prezes IPN może np. odmówić jej wydania i w jakiej formie (np. decyzji czy postanowienia) ma to nastąpić, a także czy od negatywnego rozstrzygnięcia przysługiwał będzie środek zaskarżenia i jaki.

$\mathrm{Na}$ uwagę zasługuje również okoliczność, że nie wskazano przesłanek, na podstawie których właściwy organ będzie wydawał decyzję uznaniową o zakazie ponownego użycia grobu, ani przesłanek, zgodnie z którymi będzie mógł taką decyzję uchylić, stosownie do treści art. 7a ust. 8 ustawy o cmentarzach. Nadanie rozstrzygnięciu charakteru uznaniowego (np. decyzja o przyznanie ulgi w spłacie zobowiązań podatkowych) często wiąże się ze wskazaniem chociażby ogólnych kryteriów/klauzul generalnych, którymi organ powinien się kierować przy wydawaniu decyzji. Wśród potencjalnych kryteriów można by wskazać, np. udokumentowane, znaczne dokonania osoby zmarłej w walce o niepodległość państwa polskiego, jej bohaterską postawę, interes społeczny. Podobnie, uchylenie decyzji powinno się wiązać z zaistnieniem określonych zdarzeń, np. ujawnieniem się okoliczności nieznanych podczas wydawania decyzji o zakazie wykorzystania miejsca spoczynku do ponownego pochówku, z których wynika, że dana osoba jednak nie jest osobą zasłużoną w walce o niepodległość Polski. W tym kontekście trzeba zwrócić uwagę, że możliwość uchylenia decyzji stosownie do postanowień projektu nie jest ograniczona żadnym terminem. Projekt nie zawiera także regulacji dotyczących ewentualnych rozstrzygnięć umarzających postępowanie, np. w sytuacji gdy został złożony wniosek w odniesieniu do miejsca spoczynku już wpisanego do Bazy Miejsc Spoczynku. Projekt nie reguluje także kwestii związanych $\mathrm{z}$ ewentualnym postępowaniem dowodowym związanym $\mathrm{z}$ wydawaniem decyzji.

\section{Podsumowanie}

Reasumując, należy wskazać, że ideę objęcia ochroną grobów osób walczących o niepodległość kraju, poprzez wyłączenie możliwości likwidacji grobów osób 
zasłużonych w walce o niepodległość, trzeba ocenić pozytywnie w związku z konstytucyjnym nakazem strzeżenia dziedzictwa narodowego. Inicjatywa może wywołać również pozytywne skutki społeczne w postaci zwiększenia świadomości historycznej społeczeństwa, w tym członków społeczności lokalnych. Niemniej można powziąć wątpliwości co do zgodności procedury wydawania decyzji o zakazie użycia grobu do ponownego pochówku z art. 2 Konstytucji RP, z uwagi na jej szczątkowość, co skutkuje brakiem pewności prawa. W tym zakresie zachodzi konieczność bądź to szczegółowego uregulowania odrębnej procedury, bądź odesłania do odpowiedniego stosowania przepisów Kodeksu postępowania administracyjnego. W uzasadnieniu projektu nie wskazano także szacunkowego wyliczenia kosztów związanych z wdrożeniem rozwiązań przewidzianych w projekcie, które - jak wynika z przedstawionych wyżej rozważań - mogą być znaczne. Co do skutków finansowych dla budżetu państwa, to warto przeanalizować wprowadzenie trybu przyznawania środków na utrzymanie miejsca pochówku objętego ochroną na wniosek np. członka rodziny czy organizacji społecznej zajmującej się upamiętnianiem i otaczaniem opieką miejsc pamięci narodowej.

Przed podjęciem dalszych działań legislacyjnych projekt wymaga głębszej refleksji dotyczącej konieczności wprowadzenia uzupełnień lub zmian w opisanych wyżej zakresach.

\section{Bibliografia}

Konstytucja Rzeczypospolitej Polskiej. Komentarz, t. I, red. L. Garlicki, M. Zubik, Warszawa 2016. 